\title{
PENINGKATAN KETERAMPILAN BERBICARA MELALUI METODE BERMAIN PERAN PADA SISWA SD NEGERI 58 KOTA BIMA
}

\author{
Sry Rahmawaty dan Suwarjo \\ SD Negeri 58 Kota Bima, Universitas Negeri Yogyakarta \\ Email: Sryrahmawaty90@yahoo.co.id
}

\begin{abstract}
Abstrak
Penelitian ini bertujuan untuk meningkatkan keterampilan berbicara siswa melalui penggunaan metode bermain peran pada mata pelajaran Bahasa Indonesia di SD Negeri 58 Kota Bima. Penelitian ini merupakan penelitian tindakan kelas dengan menggunakan desain penelitian Kemmis dan McTaggart. Penelitian tindakan kelas ini diimplementasikan pada siswa kelas V SD Negeri 58 Kota Bima, pada semester I tahun ajaran 2013/2014. Penelitian ini dilakukan secara kolaboratif dalam dua siklus, dengan masing-masing siklus terdiri dari tiga tindakan. Setiap siklus terdiri dari perencanaan, implementasi dan observasi, dan refleksi. Data dikumpulkan menggunakan instrumen tes unjuk kerja, dan pedoman observasi, kemudian dianalisis secara kuantitatif. Hasil penelitian menunjukkan bahwa penerapan metode bermain peran dapat meningkatkan keterampilan berbicara siswa. Hal tersebut dapat dilihat pada skor rata-rata siswa 78, 61 pada siklus 1 dengan klasifikasi baik, dan skor rata-rata siswa siklus 2 menjadi 81,04 dengan klasifikasi sangat baik. Aktivitas siswa dalam proses pembelajaran dari rata-rata 81,00 pada siklus 1 menjadi 92,00 pada siklus 2 dengan klasifikasi sangat baik. Jadi pelaksanaan tindakan menggunakan metode bermain peran telah mencapai indikator keberhasilan dalam penelitian ini yakni skor perolehan rata-rata keterampilan berbicara siswa $\geq 75,00$ dan ketuntasan belajar klassikal mencapai 75\%. Peningkatan ini disebabkan karena adanya perubahan prosedur teknik, perubahan materi, dan perubahan anggota kelompok.
\end{abstract}

Kata kunci: bermain peran, keterampilan berbicara.

\section{IMPROVING THE SPEAKING SKILLS THROUGH ROLE PLAYING METHODS OF THE STUDENTS' AT SD 58 BIMA CITIES}

\begin{abstract}
This research was aimed to improve students' speaking skills through role playing method in Bahasa Indonesia subject of SD Negeri 58 Kota Bima. This was an action research using Kemmis and McTaggart research design. This action research was implemented in Grade Vstudents of SD Negeri 58 Kota Bima on the 1st semester of 2013/2014 learning year. This research was conducted collaboratively in two cycles with each cycle consisting of three actions. Each cycle consisted of planning, implementation and observation, and reflection. The data were collected using a performance test and observational manual, then they were analyzed by descriptive quantitative. The research result showed that role playing method could improve student's speaking skills. That can be seen from student average score of 78.61 in 1st cycle with good classification, and 2nd cycle student average score was 81.04 with excellent classification. The Students' activity in learning process from average of 81.00 in 1st cycle became 92.00, in 2 nd cycle with excellent classification. Therefore role playing method had achieved a successful indicator in this research i.e. average gain score of students' speaking skill $\geq 75.00$ and classical learning completion achieved $75 \%$. This improvement was caused by thechanging of technical procedure, the materials, and group members.
\end{abstract}

Keywords: role playing, speaking skill. 


\section{PENDAHULUAN}

Kehidupan manusia tidak dapat lepas dari kegiatan berbahasa. Bahasa merupakan sarana untuk berkomunikasi antarmanusia. Bahasa sebagai alat komunikasi ini, dalam rangka memenuhi sifat manusia sebagai makhluk sosial yang perlu berinteraksi dengan sesama manusia. Proses komunikasi pada hakekatnya adalah proses penyampaian pikiran atau perasaan oleh seseorang (komunikator) kepada orang lain (komunikan). Pikiran dapat berupa gagasan, informasi maupun opini. Adapun perasaan dapat berupa keyakinan, kepastian, keraguan, kekhawatiran, kemarahan maupun keberanian. Berbicara dan berpikir mempunyai hubungan erat, kedua-duanya harus berada dalam keserasian. Jonathan Swift mengatakan: "Vlugge sprekers zijn gewoonlijk langjame denkers", yang berarti "orang-orang yang berbicara cepat biasanya lamban berpikir" (dalam Tarigan, 2008, p.29). Melalui latihan berpikir mereka memperoleh berbagai macam pengetahuan dalam memecahkan masalah yang timbul baik itu masalah yang terdapat di lingkungan keluarga maupun masyarakat. Siswa yang mempunyai keterampilan berbicara yang baik, pembicaraannya akan lebih mudah dipahami oleh penyimaknya. Berbicara menunjang keterampilan membaca dan menulis. Menulis dan berbicara mempunyai kesamaan yaitu sebagai kegiatan produksi bahasa dan bersifat menyampaikan informasi. Kemampuan siswa dalam berbicara juga akan bermanfaat dalam kegiatan menyimak dan memahami bacaan. Berbicara merupakan suatu bentuk perilaku manusia yang memanfaatkan faktor-faktor fisik, psikologis, neurologis, semantik, dan linguistik sedemikian ekstensif, secara luas sehingga dapat dianggap sebagai alat manusia yang paling penting bagi kontrol sosial. Berbicara merupakan salah satu aspek keterampilan berbahasa yang bersifat produktif, artinya suatu keterampilan yang dimiliki seseorang untuk menyampaikan gagasan, pikiran atau perasaan sehingga gagasan-gagasan yang ada dalam pikiran pembicara dapat dipahami orang lain. Berbicara berarti mengemukakan ide atau pesan lisan secara aktif melalui lambanglambang bunyi agar terjadi kegiatan komunikasi antara penutur dan mitra tutur. Keterampilan berbicara harus dikuasai oleh para siswa SD karena keterampilan ini secara langsung berkaitan dengan seluruh proses belajar siswa di SD. Keberhasilan belajar siswa dalam mengikuti proses kegiatan belajar mengajar di sekolah sangat ditentukan oleh penguasaan keterampilan berbicara mereka. Siswa yang tidak terampil berbicara dengan baik dan benar akan mengalami kesulitan dalam mengikuti kegiatan pembelajaran untuk semua mata pelajaran. Menurut Santrock (2012, p.252) penggunaan dialog sebagai alat scaffolding merupakan salah satu contoh penting peran bahasa di dalam perkembangan anak. Permasalahan dalam keterampilan berbicara terjadi pada siswa kelas V SD Negeri 58 Kota Bima. Hal ini dapat diketahui berdasarkan hasil wawancara awal dengan guru kelas pada tanggal 22 Juli 2013 yang menyatakan bahwa rendahnya keterampilan berbicara siswa kelas V SD Negeri 58 Kota Bima. Hal ini dilihat dari masih banyak siswa yang mendapat nilai dibawah KKM yang ditentukan oleh guru, dari data yang ada menunjukkan bahwa 19 siswa atau sekitar 82,61\% yang mendapat nilai 65 di atas (batas ketuntasan dari guru), sedangkan sisanya $17,39 \%$ atau sebanyak 4 siswa mendapat nilai di bawah 65, dan dari empat aspek bahasa; menyimak, berbicara, membaca dan menulis, maka aspek berbicaralah yang rata-rata siswa mendapat nilai rendah. Hal ini disebabkan karena siswa terbiasa menggunakan bahasa daerah (bahasa Bima), tidak memiliki percaya diri untuk mengungkapkan ide-ide, gagasan dan pikiran, tidak berani berbicara di depan kelas dan malu bertanya. 
Menurut guru, kegiatan berbicara selama ini masih kurang mendapat perhatian. Pembelajaran berbicara yang dilakukan guru dapat dikatakan masih sederhana atau konvensional karena masih bertumpu pada buku pelajaran. Ketergantungan pada buku pelajaran tersebut menyebabkan guru enggan untuk mengubah metode pembelajaran. Hal ini menjadi suatu acuan untuk memperbaiki pembelajaran bahasa Indonesia di Sekolah Dasar dalam hal ini kelas V (lima) SD Negeri 58 Kota Bima agar siswa memiliki perbendaharaan kata yang banyak sehingga siswa memiliki keberanian untuk mengungkapkan ide, pikiran, pendapat serta mudah dalam mengkomunikasikan perasaan. Selain itu, siswa diharapkan terbiasa menggunakan bahasa Indonesia yang baik dan benar.

Banyak upaya yang dapat dilakukan untuk memperbaiki pembelajaran bahasa Indonesia terutama dalam keterampilan berbicara. Untuk mengoptimalkan hasil belajar, terutama keterampilan berbicara, diperlukan metode yang lebih menekankan pada aktivitas belajar aktif dan kreativitas para siswa selama proses pembelajaran berlangsung. Untuk itu guru perlu mengubah metode konvensional dengan penerapan metode bermain peran. Bermain peran merupakan teknik bermain peran secara sederhana. Dalam bermain peran, siswa dibagi untuk memerankan tokoh-tokoh tertentu sesuai dengan tema pelajaran saat itu. Berdasarkan uraian di atas, maka peneliti menerapkan metode bermain peran dalam bentuk penelitian tindakan kelas. Adapun alasan pemilihan metode bermain peran adalah dengan pertimbangan bahwa metode ini dirasa lebih efektif dan lebih efisien untuk diterapkan dalam pembelajaran keterampilan berbicara. Patricia \& Amato (2003, p.222) mengatakan bahwa Role play memiliki daya tarik tinggi bagi siswa karena memungkinkan mereka untuk menjadi kreatif dan menempatkan diri di tempat orang lain untuk sementara waktu. Kerr, et.al., dalam journal of Information Systems Education v.14, n.2 bulan juli 2003, p. 1 yang berjudul The use of Role Playing to help Students Understand Information Systems Case studies. Penelitian ini bertujuan untuk meneliti Pendekatan role-playing yang memperkenalkan kasus " dunia nyata " masalah sistem informasi dalam bisnis dibandingkan dengan pendekatan tradisional membahas studi kasus untuk sistem informasi siswa universitas 32 tahun pertama. Hasil penelitian menunjukkan bahwa: a) siswa menganggap pendekatan role-play lebih unggul dari pendekatan kasus tradisional, meskipun pengamat bermain peran tidak begitu antusias sebagai peserta. b) mahasiswa menganggap pendekatan role-play membantu mereka memahami bagaimana sistem informasi dapat digunakan dalam bisnis. c.) mereka juga menganggap bahwa bermain peran meningkatkan pembelajaran mereka dan mereka merasa sangat nyaman dengan pendekatan role-playing.

Rendahnya keterampilan berbicara siswa menjadi permasalahan yang terjadi di SD Negeri 58 Kota Bima, hal ini disebabkan karena penggunaan metode dalam pembelajaran yang masih belum tepat, sehingga penelitian ini bertujuan untuk meningkatkan keterampilan berbicara siswa melalui penggunaan metode bermain peran, dan untuk meningkatkan aktifitas pembelajaran Bahasa Indonesia pada siswa SD Negeri 58 Kota Bima. Hal ini diharapkan bermanfaat baik secara teoritis maupun secara praktis bagi guru, siswa, sekolah dan peneliti berikutnya.

\section{METODE}

Jenis Penelitian

Penelitian ini menggunakan penelitian tindakan kelas, dengan menggunakan desain penelitian Kemmis dan Mc Taggart yang terdiri dari tiga tindakan yaitu: perencanaan, implementasi dan observasi, dan refleksi. 
Waktu dan Tempat Penelitian

Penelitian ini dilakukan pada semester I tahun ajaran 2013/2014, yang dilakukan selama tiga bulan yakni dari bulan Oktober sampai dengan bulan Desember sesuai dengan Standar Kompetensi yang berlaku pada SD Negeri 58 Kota Bima. Penelitian dilaksanakan sejalan dengan proses pembelajaran yang sedang berlangsung, dengan 3 kali pertemuan setiap siklus masing-masing 2 × 35 menit.

Target/Subjek Penelitian

Target/subjek penelitian adalah siswa kelas V SD Negeri 58 Kota Bima yang berjumlah 23 orang, terdiri dari 10 orang putri dan 13 orang putra.

Prosedur

Pada tahap pendahuluan (refleksi awal) kolaborator melakukan observasi langsung tentang keadaan sekolah yang akan dijadikan sebagai tempat penelitian, dengan melihat dokumentasi dan melakukan wawancara dengan guru mata pelajaran Bahasa Indonesia dan siswa kelas V SD Negeri 58 Kota Bima, yang dilakukan pada tanggal 22 Juli 2013. Data yang diperoleh melalui observasi awal ini menunjukkan bahwa keterampilan berbicara siswa rendah. Berdasarkan dokumentasi nilai siswa yang ada menunjukkan bahwa 17,39\% atau sebanyak 4 orang siswa mendapat nilai di bawah 65 yang menjadi KKM guru mata pelajaran Bahasa Indonesia, dan nilai yang terendah tersebut terdapat pada aspek berbicara. Data yang diperoleh merupakan acuan bagi penentuan masalah dan pemecahan dari masalah. Data yang diperoleh dibahas bersama dengan guru mata pelajaran Bahasa Indonesia untuk mencari solusi pemecahan masalah yang ada. Dari hasil pembicaraan dengan guru mata pelajaran tersebut disimpulkan bahwa penggunaan metode mengajar guru kurang menarik minat siswa yang berada pada usia senang bermain, sehingga pada penelitian ini diterapkan metode bermain peran untuk meningkatkan keterampilan berbicara siswa. Dengan metode bermain peran siswa menempatkan diri sebagai orang lain untuk sementara waktu dan dilakukan secara bersama-sama dengan anggota kelompok masing-masing, sehingga siswa bisa saling mendukung satu sama lain. Selanjutnya kolaborator membuat perencanaan tindakan dan menyusun perangkat yang diperlukan selama tindakan berlangsung yaitu: menyusun skenario tindakan, berupa RPP (Rencana Pelaksanaan Pembelajaran). Skenario pembelajaran berisi langkah-langkah tindakan yang dilakukan oleh guru dan kegiatan siswa ketika guru menerapkan tindakan, menyusun instrumen pengumpulan data penelitian yang terdiri dari instrumen unjuk kerja untuk menilai keterampilan berbicara siswa, lembar penilaian aktifitas siswa dalam pembelajaran, dan lembar penilaian aktifitas guru dalam pembelajaran, media pembelajaran, petunjuk belajar, dan uraian materi pembelajaran. Dalam tahap ini kolaborator melakukan hal-hal yang sudah ditetapkan dalam perencanaan yang telah dibuat, kejelasan langkah atau proses, apa yang dilakukan oleh siswa, dan sebagainya. Tindakan yang dilakukan siswa adalah: (1) membuat skenario dan memainkan peran sambil membaca skenario, (2) meringkas skenario kemudian memainkan peran sambil membaca ringkasan, dan (3) bermain peran secara natural (tanpa membaca skenario). Observasi dilaksanakan untuk mengamati proses dan dampak. Observasi proses merekam apakah proses tindakan sesuai dengan skenarionya, dan gejala-gejala apa yang timbul selama proses tindakan, baik pada guru sebagai aktor, sasaran tindakan, atau situasi yang menyertainya. Dampak tindakan yang berupa prestasi/ kompetensi dapat diukur dengan alat tes yaitu tes unjuk kerja. Evaluasi yang dilaksanakan yaitu evaluasi proses yang mana evaluasi dilakukan langsung pada saat proses belajar mengajar dengan meminta 
siswa untuk memerankan tokoh bersama anggota kelompoknya masing-masing di depan kelas untuk menilai keterampilan berbicara siswa. Pada bagian refleksi dilaksanakan analisis data mengenai proses, masalah, dan hambatan yang dijumpai dan dilanjutkan dengan refleksi terhadap dampak pelaksanaan tindakan yang dilaksanakan.

Hasil yang diperoleh dari tindakan yang dilakukan dapat meningkatkan keterampilan berbicara siswa. Hal tersebut dapat dilihat pada skor rata-rata siswa 78,61 pada siklus 1 dengan klasifikasi baik, dan skor rata-rata siswa siklus 2 menjadi 81,04 dengan klasifikasi sangat baik. Aktivitas siswa dalam proses pembelajaran dari rata-rata 81,00 pada siklus 1 menjadi 92,00 pada siklus 2 dengan klasifikasi sangat baik. Jadi pelaksanaan tindakan menggunakan metode bermain peran telah mencapai indikator keberhasilan dalam penelitian ini yakni skor perolehan rata-rata keterampilan berbicara siswa e"75,00 dan ketuntasan belajar klassikal mencapai $75 \%$. Peningkatan ini disebabkan karena adanya perubahan prosedur teknik, perubahan materi, dan perubahan anggota kelompok.

Data, Intrumen, dan Teknik Pengumpulan Data

Data yang diperoleh menunjukkan rendahnya keterampilan berbicara siswa. Data diperoleh melalui observasi langsung di sekolah dengan melakukan wawancara dengan guru mata pelajaran Bahasa Indonesia, dan dengan melihat dokumentasi hasil penilaian siswa. Data dikumpulkan berdasarkan instrumen pengumpulan data. Teknik pengumpulan data yang digunakan pada penelitian ini adalah teknik tes dan non tes, yang berupa: 1) Tes merupakan sebuah instrumen atau prosedur yang sistematis untuk mengukur suatu sampel tingkah laku yang jawabnya berupa angka, Gronlund (Nurgiyantoro, 2012, p.105). Tes adalah cara untuk menda- patkan informasi mengenai kompetensi, pengetahuan, dan keterampilan siswa. Jenis-jenis tes terdiri dari tes lisan, tes tertulis, dan tes perbuatan. Teknik tes yang dilakukan dalam penelitian ini adalah tes perbuatan/unjuk kerja. Teknik tes unjuk kerja ini dilakukan pada saat proses belajar mengajar berlangsung dengan cara menilai keterampilan berbicara siswa pada saat siswa melakukan kegiatan bermain peran. Nilai yang diperoleh siswa yang satu tidak mempengaruhi nilai siswa yang lainnya. 2) Observasi yang merupakan teknik pengumpulan data yang dilakukan dengan jalan pengamatan dan pencatatan secara sistematis, logis, objektif dan rasional mengenai berbagai fenomena, baik dalam situasi yang sebenarnya maupun dalam situasi buatan untuk mencapai tujuan tertentu. Tujuan utama observasi yaitu: a) untuk mengumpulkan data dan informasi mengenai suatu fenomena, baik yang berupa peristiwa maupun tindakan, baik dalam situasi yang sesungguhnya maupun dalam situasi buatan, b) untuk mengukur tindakan, perilaku dan proses atau kegiatan yang sedang dilakukan, interaksi antara responden dan lingkungan, dan faktor-faktor yang dapat diamati lainnya, terutama kecakapan sosial (social skills). Lembar observasi/pengamatan digunakan untuk mengamati pelaksanaan proses pembelajaran ketika pelaksanaan tindakan, dengan kisi-kisi instrumen untuk siswa: kerjasama, tanggungjawab, inisiatif, dan keberanian, sedangkan kisi-kisi instrumen untuk guru meliputi: kegiatan awal, kegiatan inti; penguasaan materi, penggunaan strategi/pendekatan, pemanfaatan sumber belajar/media, melibatkan siswa dalam proses pembelajaran, penilaian proses dan hasil belajar siswa, dan penggunaan bahasa. 3) Dokumentasi merupakan pengambilan gambar berupa foto-foto pada saat proses pembelajaran berlangsung dengan menggunakan metode bermain peran. Dokumentasi ini berfungsi untuk menjadi bukti mengenai 
adanya proses kegiatan bermain peran, dan melalui dokumentasi ini juga dapat menjadi suatu cara mengantisipasi adanya kekeliruan atau kesalahan dalam proses penilaian. 4) Wawancara yang dilakukan berhubungan dengan keadaan keterampilan berbicara siswa, proses pembelajaran dan hal-hal yang terkait dengan kebutuhan penelitian. Wawancara ini dilakukan tidak terstruktur atau tidak terjadwal karena dilakukan disetiap membutuhkan data pendukung. Wawancara dilakukan terhadap guru, kepala sekolah dan siswa.

\section{Teknik Analisis Data}

Analisis data pada dasarnya bertujuan mengolah informasi kuantitatif maupun kualitatif. Sementara menurut Muliyatiningsih (2011, p.38) bahwa teknik analisis data ditentukan oleh jenis data dan skala pengukuran. Untuk menganalisis data dalam penelitian ini digunakan analisis kuantitatif. Data kuantitatif adalah informasi yang muncul di lapangan dan memiliki karakteristik yang dapat ditampilkan dalam bentuk angka (Pardjono, dkk, 2007, p.53). Analisis Kuantitatif adalah data yang berhubungan dengan angka-angka atau bilangan, baik yang diperoleh dari hasil pengukuran maupun diperoleh dengan jalan mengubah data kualitatif menjadi data kuantitatif. Data kuantitatif digunakan untuk menganalisis data-data kuantitatif yang diperoleh dalam penelitian. Penafsiran hasil tes kompetensi berbicara siswa berdasarkan pada KKM yang ditetapkan guru meliputi kemampuan dalam: tata bahasa, kosa kata, pemahaman, kefasihan dan pengucapan. Kategori pemberian skor hasil tes mengacu pada model penilaian yang digunakan untuk menilai wawancara dalam bahasa kedua (bahasa asing, bahasa inggris) oleh Brown, 2004. Model ini mencakup enam komponen yaitu: tata bahasa, kosa kata, pemahaman, kefasihan pengucapan dan tugas, yang keenamnya saling berkaitan, namun karena yang menjadi subjek pe- nelitian adalah siswa SD maka penilaian aspek tugas tidak digunakan karena tidak sesuai dengan keadaan. Model ini hanya mencakup komponen kebahasaan saja, dan tidak mengukur komponen gagasan, yang disesuaikan dengan penilaian yang berlaku pada satuan pendidikan tempat penelitian tindakan dilaksanakan. Hasil ini digunakan untuk mengetahui tingkat ketuntasan dan perubahan belajar yang dicapai siswa dalam mempelajari kompetensi berbicara yang diajarkan, kemudian digunakan sebagai salah satu pengukur keberhasilan metode bermain peran sebagai metode pembelajaran yang dapat meningkatkan kompetensi berbicara siswa. Untuk menganalisis data kuantitatif hasil belajar berupa tes unjuk kerja saat penampilan bermain peran, maka data yang telah dikumpulkan dianalisis dengan mengikuti langkah-langkah sebagai berikut: a) Penskoran menggunakan numerical rating scale dengan rentang 1 sampai 5, (Widoyoko, 2013). Menurut Asmawi Zaenul dan Noehi Nasution (dalam Widoyoko, 2013, pp.109-110), rating scale adalah instrumen pengukuran nontes yang menggunakan suatu prosedur terstruktur untuk memperoleh informasi tentang sesuatu yang diobservasi yang menyatakan posisi tertentu dalam hubungannya dengan yang lain. b) Mengubah skor menjadi nilai untuk menentukan nilai hasil belajar dengan rumus:

$\frac{\text { skor yang diperoleh }}{\text { skor maksimum }} \times 100$

(Suwandi, 2009, p.127). c) Memberi tafsiran berupa pengkategorian atas hasil penghitungan. Agar data yang diperoleh dapat bermakna, maka perlu dibuat kategori berdasarkan persentase.

\section{HASIL DAN PEMBAHASAN}

Kondisi Lingkungan Sekolah

SD Negeri 58 Kota Bima adalah salah satu sekolah yang berada di kecamatan Asakota Kota Bima propinsi Nusa Tengg- 
ara Barat (NTB). SDN 58 Kota Bima berada satu atap dengan Taman Kanak-kanak Mutmainah, sehingga output dari Taman Kanak-kanak tersebut langsung masuk ke SD Negeri 58 Kota Bima. Fasilitas sarana dan prasarana yang tersedia di sekolah belum cukup memadai, media pembelajaran yang tersedia juga masih kurang.

Lokasi sekolah berada di tepi jalan raya namun aman dan kondusif, berada di lingkungan area yang tidak terlalu padat penduduknya. Sekolah Dasar Negeri 58 Kota Bima seringkali dijadikan sebagai tempat pertemuan guru dan berbagai perlombaan lingkup kecamatan Asakota karena lingkungannya yang asri dan sejuk. Disekitar sekolah tersebut terdapat Sekolah Menengah Pertama (SMP) dan Sekolah Menengah Atas (SMA). Tepatnya di jalan Karantina Baru kelurahan Jatiwangi. Sehingga untuk melanjutkan sekolah ke jenjang berikutnya siswa mayoritas langsung masuk sekolah yang berada di sekitar itu. Siswa rata-rata berdomisili disekitar sekolah, jarak tempuh untuk ke sekolah cukup dekat, sehingga untuk mencapai sekolah peserta didik cukup dengan jalan kaki.

\section{Kondisi Siswa}

Pada tahun ajaran 2012/2013, rombongan belajar SD Negeri 58 Kota Bima adalah 220 orang. Jumlah siswa setiap tahun cenderung stabil, dan berasal dari latar belakang yang berbeda. Perubahan jumlah siswa tiap tahun ajaran baru tidak mengalami peningkatan yang signifikan karena mengingat jarak sekolah dasar yang satu dengan yang lainnya tidak terlalu jauh sedangkan jumlah penduduk tidak terlalu banyak.

Kondisi Siswa PraTindakan

Materi ajar yang diterapkan di SD Negeri 58 Kota Bima berdasarkan KTSP, dengan metode yang bersifat konfesional, sehingga keterampilan berbicara siswa masih kurang. Hal ini juga disebabkan karena pengaruh penggunaan bahasa ibu yang biasa digunakan siswa setiap hari. Se- bagai indikator keberhasilan pembelajaran bahasa Indonesia yang diharapkan adalah siswa mampu dan terampil berbahasa secara baik dan benar dengan memperhatikan santun berbahasa, dan salah satu aspek bahasa tersebut adalah berbicara. Namun dilihat dari hasil praktek berbicara siswa belum ditemukan kompetensi seperti yang diharapkan. Siswa terbiasa berbicara dengan menggunakan bahasa ibu baik dalam kelas maupun di luar kelas. Ketika peneliti mengajak siswa berbicara, siswa terlihat malu-malu dan tidak merespon, dan menjawabnya dengan bahasa campuran bahasa indonesia dengan bahasa daerah Bima.

Sebab-Sebab Masalah dan Upaya Pemecahannya

Berdasarkan hasil pengamatan awal yang dilakukan pada bulan Juli 2013 yang kemudian didiskusikan bersama guru mata pelajaran bahasa Indonesia kelas $\mathrm{V}$, maka ditemukan beberapa permasalahan yang menyebabkan siswa kurang terampil berbicara. Permasalahan ini disebabkan oleh belum optimalnya pengelolaan pembelajaran yang dilakukan oleh guru, sehingga siswa tidak tertarik untuk mengikuti pembelajaran secara optimal. Disamping itu, hal ini juga disebabkan oleh kurangnya pembiasaan penggunaan bahasa Indonesia baik oleh orang tua/keluarga di rumah dan di masyarakat maupun di lingkungan sekolah.

Berdasarkan permasalahan sebagai hasil temuan tersebut, maka peneliti dan guru mata pelajaran berupaya merubah metode mengajar dengan maksud untuk menarik minat belajar siswa sehingga keterampilan berbicara siswa bisa meningkat. Metode yang akan digunakan adalah metode bermain peran. Metode bermain peran ini dipilih karena didasarkan pada kebahasaan dan perkembangan siswa. Pada usia sekolah dasar siswa senang bermain sambil belajar atau belajar sambil bermain. Pada saat melakukan simulasi 
bermain peran dimungkinkan siswa dapat mengungkapkan ide-ide atau gagasan, pendapat dan dapat mengekspresikan diri, dengan demikian keterampilan berbicara siswa akan meningkat.

Penelitian yang dilakukan adalah penelitian tindakan kelas dengan menggunakan model Kemmis \& Taggart melalui dua siklus berulang dengan tiga langkah; perencanaan, tindakan dan observasi, refleksi sampai diperoleh data yang diharapkan dari penelitian tindakan.

Penelitian tindakan dilaksanakan selama kurang lebih tiga bulan mulai dari bulan Oktober sampai bulan Desember tahun 2013 dengan berpedoman pada kajian pustaka yang telah dilaksanakan dengan metode penelitian yang telah dipilih. Hasil penelitian diperoleh dari pengumpulan data dengan berbagai teknik yang dilakukan oleh guru, peneliti dan kolaborator. Pengumpulan data dilakukaan sebelum, selama dan sesudah pelaksanaan tindakan. Data sebelum tindakan diperoleh dari hasil observasi awal berdasarkan informasi dan data dari guru mata pelajaran Bahasa Indonesia. Data ini akan dijadikan sebagai bahan perbandingan dengan hasil yang diperoleh setelah diberi tindakan, agar bisa diketahui apakah ada peningkatan keterampilan berbicara siswa atau tidak. Jika keadaan keterampilan berbicara siswa mengalami peningkatan berarti penerapan metode bermain peran dalam penelitian ini berhasil.

Dari hasil pratindakan tersebut dapat diketahui bahwa keterampilan berbicara sebagian besar siswa rendah, karena $39,13 \%$ berada di posisi cukup baik dan $17,39 \%$ berada di posisi kurang baik yang disebabkan karena penggunaan metode yang tidak tepat, tidak disesuaikan dengan tingkat perkembangan siswa yang pada usia sekolah dasar siswa senang belajar sambil bermain atau bermain sambil belajar.
Tabel 1. Keadaan Keterampilan Berbicara Siswa Pratindakan

\begin{tabular}{ccc}
\hline Kategori & Frekuensi & $\begin{array}{c}\text { Persentase } \\
\mathbf{( \% )}\end{array}$ \\
\hline Sangat baik & 0 & 0,00 \\
Baik & 10 & 43,48 \\
Cukup & 9 & 39,13 \\
Tidak baik & 4 & 17,39 \\
Sangat kurang & 0 & 0,00 \\
Jumlah & 23 & 100,00 \\
\hline
\end{tabular}

Pada bagian ini disajikan deskripsi mengenai tindakan yang dilakukan dari siklus persiklus. Kendati demikian, terlebih dahulu disampaikan gambaran observasi awal yang dilakukan oleh kolaborator di kelas tindakan. Tujuan dari observasi awal adalah untuk mengetahui permasalahan yang dialami siswa untuk dipecahkan dalam penelitian tindakan. Observasi awal dilakukan pada awal semester I bulan Juli di kelas V SD Negeri 58 Kota Bima yang merupakan kelas yang ditetapkan sebagai kelas yang akan diberi tindakan.

Berikut gambaran situasi kelas saat observasi awal dilakukan:

Guru bersama kolaborator masuk di kelas V pada hari Senin tanggal 22 Juli 2013 saat proses belajar mengajar berlangsung. Tampak sebagian besar siswa tidak serius mengikuti pelajaran. Sebagian siswa terlihat memperhatikan guru dengan pandangan kosong, dan sebagiannya lagi sibuk bercerita sendiri terutama siswa yang posisi duduknya di bagian belakang siswa nampak saling mengganggu. Sesekali guru menegur dan sesaat perhatian siswa tertuju pada guru yang memberi materi namun tidak lama kemudian siswa kembali acuh tak acuh. Berdasarkan informasi dari guru kelas, ternyata keadaan seperti ini merupakan pemandangan setiap hari efektif sekolah, hal ini disebabkan karena siswa merasa tidak tertarik dengan proses pembelajaran yang berlangsung yang hanya didominasi dengan ceramah dari guru. Ketika guru memberikan kesempa- 
tan untuk bertanya, semua siswa terdiam seakan sudah mengerti dan memahami semua materi yang telah di sampaikan oleh guru, padahal ketika guru bertanya tentang materi yang telah di sampaikan hanya beberapa siswa saja yang mengangkat tangan dan menjawab dengan ragu seakan mereka tidak punya keberanian untuk berbicara. Pada saat guru memberi tugas kelompokpun hanya beberapa anggota saja yang aktif sedangkan sebagian besar anggota kelompok pasif tidak berani mengungkapkan pendapat dan ide.

Berdasarkan hasil observasi awal tersebut kemudian didiskusikan dengan guru mata pelajaran. Kegiatan pembelajaran yang tampak dalam gambaran tersebut di atas menunjukkan bahwa sebagian besar siswa tidak berani dan tidak terampil berkomunikasi untuk mengungkapkan ide, gagasan, pendapat, pertanyaan maupun menjawab pertanyaan guru, lebihlebih lagi untuk tampil di depan kelas sebagian besar siswa kurang percaya diri. Intinya bahwa siswa belum berpartisipasi secara maksimal, dan belum menunjukkan rasa senang selama mengikuti pembelajaran. Berdasarkan permasalahan tersebut, kolaborator bersama guru mata pelajaran Bahasa Indonesia menetapkan upaya untuk meningkatkan keterampilan berbicara siswa dengan melakukan pembelajaran yang memberikan banyak kesempatan kepada siswa untuk berpartisipasi aktif. Penerapan metode bermain peran dapat menumbuhkan rasa senang, keberanian, dan keaktifan secara menyeluruh dalam diri siswa. Penggunaan metode ini bertujuan untuk meningkatkan keterampilan berbicara siswa. Pelaksanaan tindakan dimulai pada tanggal 8 Oktober 2013. Penentuan materi berdasarkan kompetensi dasar dan kesepakatan dengan guru Mata Pelajaran Bahasa Indonesia.

Data sebelum tindakan diperoleh dari hasil observasi awal berdasarkan informasi dan data dari guru mata pelajaran Bahasa Indonesia. Data ini akan dijadikan sebagai bahan perbandingan dengan hasil yang diperoleh setelah diberi tindakan, agar bisa diketahui apakah ada peningkatan keterampilan berbicara siswa atau tidak. Jika keadaan keterampilan berbicara siswa pascatindakan mengalami peningkatan berarti penerapan metode bermain peran dalam penelitian ini berhasil. Dari hasil pratindakan diketahui bahwa keterampilan berbicara sebagian besar subjek penelitian rendah, karena 39,13\% berada di posisi cukup dan 17,39\% berada di posisi kurang yang disebabkan karena penggunaan metode yang tidak tepat, tidak disesuaikan dengan tingkat perkembangan subjek penelitian yang pada usia sekolah dasar siswa senang belajar sambil bermain atau bermain sambil belajar. Kegiatan pembelajaran yang tampak pada saat dilakukan observasi menunjukkan bahwa sebagian besar siswa tidak berani dan tidak terampil berkomunikasi untuk mengungkapkan ide, gagasan, pendapat, pertanyaan maupun menjawab pertanyaan guru, lebih-lebih lagi untuk tampil di depan kelas sebagian besar siswa kurang percaya diri. Intinya bahwa siswa belum berpartisipasi secara maksimal, dan belum menunjukkan rasa senang selama mengikuti pembelajaran. Hasil refleksi menunjukkan bahwa ada beberapa permasalahan yang dijumpai dalam pembelajaran bahasa Indonesia di kelas V, antara lain: a) keterampilan berbicara siswa rendah. Kenyataan ini terindikasi dari ketidakmampuan siswa dalam menyampaikan pendapat, ide, gagasan, komentar ataupun cerita dalam bentuk lisan, $b$ ) siswa merasa takut dan malu untuk berbicara di depan kelas karena ketidakmampuannya untuk berkomunikasi dengan baik, c) metode yang digunakan guru kurang menarik siswa, karena metode yang digunakan guru tidak efektif dan efisien, yang mana guru kurang kreatif untuk menggunakan metode yang menyenangkan. Guru juga kurang memahami faktor perkembangan siswa yang pada umur itu menginginkan 
belajar sambil bermain atau bermain sambil belajar.

Berdasarkan permasalahan tersebut, kolaborator bersama guru mata pelajaran Bahasa Indonesia menetapkan upaya untuk meningkatkan keterampilan berbicara siswa dengan melakukan pembelajaran yang memberikan banyak kesempatan kepada siswa untuk berpartisipasi aktif. Dalam kegiatan pembelajaran yang dimaksud akan digunakan metode bermain peran dengan menerapkan pemodelan berdasarkan teori Albert Bandura. Penerapan metode bermain peran dapat menumbuhkan rasa senang, keberanian, dan keaktifan secara menyeluruh dalam diri siswa. Penggunaan metode ini bertujuan untuk meningkatkan keterampilan berbicara siswa. Sebelum pelaksanaan tindakan, perlu dilakukan penyusunan langkah-langkah yang akan dilakukan selama proses pembelajaran. Langkahlangkah yang dimaksud antara lain adalah menentukan pembatasan materi yang akan diberikan, membentuk kelompok bermain peran, mempersiapkan instrumen pembelajaran dan instrumen penilaian. Hal ini bertujuan agar semua komponen yang diperlukan dapat dikelola serta mendukung terlaksananya penelitian secara lancar, runtut dan sistematis. Penentuan materi ajar dirumuskan sebelum dilaksanakan tindakan siklus I. Pertimbanganpertimbangan untuk merumuskan materi ajar didasarkan pada silabus model KTSP Bahasa Indonesia dengan penekanan pada keterampilan berbicara. Metode pembelajaran digunakan untuk membantu proses pembelajaran. Dalam penelitian ini sebagai metode pokok untuk mencapai tujuan penelitian, kolaborator menggunakan metode bermain peran dengan didukung oleh metode-metode dan model pembelajaran lain. Prosedur kegiatan pembelajaran dirancang untuk melaksanakan pembelajaran berbicara. Kegiatan diupayakan untuk melibatkan semua siswa dapat berinteraksi dengan bermain peran.
Pelaksanaan Siklus I.

Rencana dan langkah pembelajaran yang dilaksanakan pada siklus I dengan kompetensi dasar wawancara, yang dilakukan melalui bermain peran: Kegiatan Pembuka: (1) Guru membuka pertemuan dengan mengucapkan salam dan cek kehadiran peserta didik. (2) Guru mengajak siswa untuk berdoa bersama. (3) Guru memotivasi siswa dengan melakukan appersepsi. (4) Guru memperkenalkan materi pada siswa. Kegiatan inti: (1) Guru melakukan tanya jawab dengan siswa sebagai upaya melihat keterampilan berbicarasiswa. (2) Guru dan siswa mendiskusikan mengenai konteks dari bermain peran. (3) Guru mengarahkan siswa untuk membentuk kelompok dengan tiga orang anggota untuk mendiskusikan tentang skenario dan pembagian peran serta mempertimbangkan konteks dan karakteristik peran. (4) Guru menyajikan model ekspresi dan penampilan berbicara dengan dibantu oleh dua orang siswa dan siswa yang lain mendengar dan memperhatikan ekspresi guru. (5) Guru membangun kompetensi siswa dengan metode bermain peran dan siswa meniru dan mengulang model yang dicontohkan oleh guru (6) Guru membangun kreatifitas berbicara individu dan/ atau kelompok dan mendorong mereka untuk berpatisipasi aktif dalam aktivitas bermain peran, dan siswa berpasangan praktik berdialog sesuai dengan peran yang akan dilakoni dalam bermain peran. (7) Siswa yang berperan sebagai penonton mendiskusikan aspek-aspek dari bermain peran dan mengekspresikan gagasangagasan dan reaksi mereka terhadap situasi yang telah ditampilkan. Kegiatan Penutup: (1) Guru menyimpulkan materi yang dipelajari. (2) Guru memberi tugas pada siswa untuk mencari materi/bahan sesuai dengan peran yang akan dilakoni pada saat praktek bermain peran sesuai dengan kesepakatan bersama anggota kelompok untuk menambah kualitas materi maupun penampilan. (3) Guru menutup 
kegiatan pembelajaran dengan doa dan salam. Penilaian yang dilakukan untuk melihat indikator keberhasilan keterampilan berbicara siswa adalah menggunakan penilaian proses. Proses pembelajaran didesain dalam tiga kali pertemuan. Pertemuan pertama dilakukan pada hari Selasa tanggal 8 Oktober 2013. Pada pertemuan pertama siswa dimotivasi untuk berinteraksi dengan guru, dengan sesama siswa dan diarahkan untuk membentuk kelompok lalu diberi tugas untuk menyusun naskah wawancara tentang tokoh yang dia inginkan (petani, pedagang atau pegawai) untuk diperankan dalam bentuk bermain peran. Pada pertemuan pertama ini setelah siswa membuat naskah, bersama anggota kelompok masing-masing maju ke depan kelas untuk melakukan simulasi (bermain peran) bersama anggota kelompoknya dengan membaca naskah, sedangkan kelompok yang tidak tampil (audiens) memberi tanggapan terhadap penampilan kelompok yang telah bermain peran. Pada pertemuan kedua tanggal 9 Oktober 2013 dilanjutkan dengan kegiatan bermain peran dengan membaca naskah bagi kelompok yang belum tampil pada pertemuan pertama karena keterbatasan waktu, kemudian dilanjutkan dengan kegiatan; semua siswa bersama dengan anggota kelompok yang telah dibentuk sebelumnya meringkas naskah yang telah di buat pada pertemuan sebelumnya untuk dibacakan dengan cara bermain peran, sedangkan kelompok yang tidak tampil memberi tanggapan terhadap penampilan kelompok yang telah bermain peran. Pada pertemuan ketiga, naskah yang telah diringkas pada pertemuan sebelumnya disimulasikan bersama anggota kelompok yang telah dibentuk sebelumnya secara natural di depan kelas. Dalam proses pelaksanaan bermain peran pada pertemuan ketiga tanggal 12 Oktober 2013 guru memberikan penilaian keterampilan berbicara siswa. Hasil refleksi berdasarkan pengamatan pada proses pembelajaran
1 sampai pembelajaran 3 pada siklus I, melalui pengamatan dan penilaian proses menghasilkan kesimpulan sementara sebagai hasil upaya peningkatan keterampilan berbicara Bahasa Indonesia yaitu: metode bermain peran sebagai metode utama dalam pembelajaran berbicara pada siswa kelas V SD Negeri 58 Kota Bima, dapat meningkatkan keterampilan berbicara siswa, memberi peluang agar siswa tidak malu dan takut untuk berbicara di depan kelas. Peningkatan ini berdasarkan hasil penilaian yang dilakukan selama proses bermain peran yang dilakukan oleh siswa bersama anggota kelompoknya masingmasing.

Tabel 2. Data Keterampilan Berbicara siswa pada Siklus I

\begin{tabular}{clcc}
\hline Kriteria & Kategori & Frekuensi & Persentase \\
\hline 5 & sangat baik & 4 & $17,39 \%$ \\
4 & baik & 19 & $82,61 \%$ \\
3 & cukup & 0 & $0 \%$ \\
2 & kurang & 0 & $0 \%$ \\
1 & sangat kurang & 0 & $0 \%$ \\
Jumlah & & 23 & $100 \%$ \\
\hline
\end{tabular}

Aktifitas proses pembelajaran keterampilan berbicara melalui penggunaan metode bermain peran bagi guru maupun peserta didik pada siklus I berjalan dengan baik. Intinya bahwa pelaksanaan tindakan pada siklus I pada dasarnya sudah berhasil, hal ini dilihat dari hasil peningkatan keterampilan berbicara siswa yang mengalami kemajuan yang signifikan.

Peningkatan ini berdasarkan hasil penilaian yang dilakukan selama proses bermain peran yang dilakukan oleh siswa bersama anggota kelompoknya masingmasing.

Aktifitas proses pembelajaran keterampilan berbicara melalui penggunaan metode bermain peran bagi guru maupun siswa pada siklus I berjalan dengan baik.

Hal-hal yang perlu ditingkatkan: (a) pengelolaan kelas, mengarahkan siswa untuk membentuk kelompok membuat 
suasana gaduh karena siswa menawarkan anggota berdasarkan keinginan mereka meskipun sudah dibagi secara adil berdasarkan tingkat kemampuan dan kecerdasan siswa. Masalah lain yang timbul adalah; bekerja kelompok untuk membuat skenario, melakukan simulasi bermain peran dan menanggapi penampilan kelompok lain memerlukan waktu yang agak lama, sehingga guru harus mampu mengatur waktu seefisien mungkin, karena guru juga harus memberikan komentar atau tanggapan sebagai bentuk apresiasi terhadap kegiatan siswa, (b) kegiatan belajar siswa, tujuan penelitian ini adalah peningkatan keterampilan berbicara siswa, sehingga kesempatan berlatih siswa harus diselaraskan dengan jenis aktifitas yang tersedia selama proses belajar mengajar. Siswa diharapkan dapat mengekspresikan dan merespon ungkapan-ungkapan sesuai kompetensi dasar, dalam hal ini diperlukan peningkatan kegiatan pembelajaran yang membimbing siswa saling bertukar informasi untuk mendukung keterampilan berbicara dengan cara bermain peran, (c) peningkatan aspek-aspek keterampilan berbicara, meliputi

\section{(1) Aspek tata bahasa}

Hasil tes berbicara dari aspek tata bahasa siswa pada akhir siklus I sudah menunjukkan hasil yang baik dengan rata-rata kelas 3,65, namun guru dan kolaborator merasa masih perlu meningkatkan kompetensi tata bahasa siswa untuk memperoleh kejelasan kalimat yang dapat dipahami maknanya.

\section{(2) Aspek kosakata}

Hasil tes praktik berbicara dari aspek kosakata siswa pada akhir siklus I juga sudah berhasil baik dengan rata-rata kelas 3,65 , namun guru dan kolaborator ingin meningkatkan lagi kompetensi kosakata untuk memperoleh keutuhan kalimat sehingga dapat dipahami maknanya dan agar siswa memiliki kosakata yang banyak untuk mengungkapkan ide-ide yang ingin disampaikan.

\section{(3) Aspek pemahaman}

Hasil tes praktik berbicara dari aspek pemahaman siswa pada akhir siklus I sudah berhasil dengan baik dengan rata-rata kelas 4,00, namun guru dan kolaborator ingin meningkatkan kompetensi pemahaman siswa terhadap kalimat yang diungkapkan, sehingga siswa dapat merespon dengan tepat apa yang dimaksudkan oleh penutur. Pada saat menyampaikan pesanpun masih banyak siswa yang tampak tidak menjiwai pesan yang disampaikan karena siswa tidak memahami sepenuhnya makna pesan yang disampaikannya.

\section{(4) Aspek Kefasihan}

Hasil tes praktik berbicara dari aspek kefasihan siswa pada akhir siklus I sudah berhasil dengan baik dengan rata-rata kelas 4,00, namun guru dan kolaborator ingin meningkatkan kompetensi kefasihan siswa dalam pengucapan. Pada saat menyampaikan pendapat atau pesan masih ada siswa yang kedengarannya terbatabata dalam mengucapkan kalimat, hal ini disebabkan karena siswa terbiasa berbicara menggunakan bahasa ibu dalam kegiatan sehari-hari.

\section{(5) Aspek Pengucapan}

Hasil tes keterampilan berbicara dari aspek pengucapan yang dilakukan pada siklus I menunjukkan bahwa kompetensi pengucapan siswa sudah berhasil dengan baik dengan rata-rata kelas 4,35, namun guru dan kolaborator ingin meningkatkan kompetensi pengucapan siswa. Setiap siswa memiliki potensi yang berbedabeda, sehingga ada yang lancar dan ada yang kurang lancar dalam pengucapan yang diakibatkan oleh pergaulan seharihari yang cenderung menggunakan bahasa ibu untuk menyampaikan pesan. Hasil tes keterampilan berbicara pada akhir siklus I menunjukkan bahwa keterampilan 
berbicara siswa sudah optimal, namun guru dan kolaborator merasa yakin kalau keterampilan berbicara siswa masih bisa ditingkatkan lagi.

Intinya bahwa pelaksanaan tindakan pada siklus I pada dasarnya sudah berhasil, hal ini dilihat dari hasil peningkatan keterampilan berbicara siswa yang mengalami kemajuan yang signifikan. Hal ini ditunjang oleh pengelolaan yang optimal dari semua aspek baik perencanaan, materi, metode maupun pelaksanaan tindakan.

Untuk menindaklanjuti kesimpulan hasil penelitian tindakan pada siklus I, maka dilakukan tindakan pada siklus II dengan penekanan pada semua aspek keterampilan berbicara yaitu aspek tata bahasa, kosakata, pemahaman, kefasihan, dan pengucapan. Tindakan ini dilakukan dengan maksud untuk meningkatkan keterampilan berbicara karena berbicara merupakan puncak dari seluruh keterampilan berbahasa dan penunjang bagi mata pelajaran yang lainnya.

\section{Pelaksanaan Siklus II}

Berangkat dari hasil refleksi yang telah dilakukan secara bersama-sama oleh kolaborator dan guru mata pelajaran pada tindakan yang dilakukan pada siklus I, yang mana didapatkan beberapa kesimpulan permasalahan antara lain adalah bahwa masih ada siswa yang memperoleh hasil belajar keterampilan berbicara yang belum memenuhi target kolaborator meskipun sudah mengalami peningkatan dan masih ada siswa yang merasa sedikit malu-malu untuk tampil di depan kelas, maka dilakukan tindakan siklus II, dengan penekanan pada semua aspek keterampilan berbicara yaitu aspek tata bahasa, kosakata, pemahaman, kefasihan, dan pengucapan. Tindakan ini dilakukan dengan maksud untuk meningkatkan keterampilan berbicara karena berbicara merupakan puncak dari seluruh keterampilan berbahasa dan penunjang bagi mata pelajaran yang lainnya. Guru dan peneliti menentukan alternatif pemecahan masalah sebagai berikut: a) merubah struktur teknik pelaksanaan tindakan, dimana pada siklus I yang berperan sebagai model adalah guru dan dua orang siswa, namun pada pelaksanaan siklus II akan digunakan media audiovisual untuk menampilkan model dialog singkat, b) merubah materi dan tambahan frekwensi latihan berbicara dalam bentuk komunikasi interaktif pada semua aspek yang terdiri dari tatabahasa, kosakata, pemahaman, kefasihan dan pengucapan, dan c) merubah keanggotaan kelompok yang dianggap tidak bisa bekerjasama agar siswa dapat saling mendukung satu sama lain.

Pertemuan pertama pada siklus II dilaksanakan pada tanggal 15 Oktober 2013. Pada bagian pendahuluan dalam kegiatan ini guru mengawali pembelajaran dengan appersepsi dan motivasi yang mengarah pada tujuan pembelajaran. Kemudian guru menyampaikan tujuan pembelajaran serta metode yang digunakan, Pada kegiatan inti guru menjelaskan bahwa tema dari pembelajaran keterampilan berbicara dengan bermain peran pada saat itu akan diganti dengan "tokoh yang dikagumi", siswa tampak senang karena diberi kesempatan untuk memilih tokoh yang akan diperankan. Guru dan kolaborator segera mempersiapkan media audio visual untuk memutar vidio dialog singkat. Siswa merasa senang sekali karena akan diperlihatkan model dialog melalui media tersebut, karena menurut siswa, proses pembelajaran menjadi terasa santai dan menyenangkan. Anggota kelompok yang dinilai tidak bisa bekerja sama diganti dengan maksud agar siswa dapat saling mendukung antara satu dengan yang lainnya. Guru memberi kesempatan kepada siswa untuk membuat skenario wawancara yang akan diperankan bersama anggota kelompok di depan kelas dengan membaca skenario, sedangkan siswa yang berperan sebagai penonton memberi tanggapan 
terhadap penampilan kelompok yang bermain peran. Siwa kelihatan antusias untuk segera melakukan simulasi bermain peran untuk menunjukkan keterampilan berbicara siswa yang terinspirasi dari percakapan melalui audio visual.

Richards (2002, p.208) mengemukakan bahwa faktor kunci dari perkembangan bahasa asing adalah kesempatan yang diberikan pada siswa untuk berbicara dalam interaksi. Kaitannya dengan teori tersebut bahwa bahasa Indonesia merupakan bahasa kedua, karena siswa berangkat dari bahasa ibu yang kental. Oleh karena itu guru hendaknya membangkitkan keinginan dan kebutuhan siswa untuk berbicara. Teori ini memandang bahwa semakin sering siswa mendapat peluang berinteraksi, akan meningkatkan keterampilan dan kelancaran berbicara siswa. Pada kegiatan penutup, guru memberikan kesimpulan dan menanggapi hasil penampilan semua anggota kelompok pada pertemuan saat itu.

Tindakan pertemuan kedua dilakukan pada tanggal 16 Oktober 2013. Secara umum, bagian pendahuluan pada pertemuan kedua siklus II sama dengan pertemuan sebelumnya, yaitu guru mengawali pembelajaran dengan appersepsi dan motivasi yang mengarah pada tujuan pembelajaran. Kemudian guru menyampaikan tujuan pembelajaran. Pada bagian inti, guru memberikan tugas pada siswa untuk menyimpulkan skenario yang telah dibuat pada pertemuan pertama lalu diperankan dengan membaca ringkasan skenario tersebut bersama anggota kelompoknya di depan kelas, sedangkan siswa yang berperan sebagai penonton diberi kesempatan untuk menanggapi penampilan anggota kelompok yang bermain peran. Pada kegiatan penutup, guru menyimpulkan dan menanggapi hasil penampilan para anggota kelompok sekaligus memberikan penguatan pada siswa agar memiliki keberanian dan rasa percaya diri untuk berbicara di depan kelas.
Tindakan pertemuan ketiga pada siklus II dilakukan pada tanggal 19 Oktober 2013. Pada dasarnya pertemuan ketiga siklus II adalah sama dengan kegiatan pada pertemuan sebelumnya, yaitu pada kegiatan awal guru mengawali pembelajaran dengan appersepsi dan motivasi yang mengarah pada tujuan pembelajaran. Kemudian guru menyampaikan tujuan pembelajaran. Pada kegiatan inti, guru memberi kesempatan kepada siswa untuk latihan pemantapan sejenak bersama anggota kelompoknya di tempat duduk kelompok masing-masing karena penampilan siswa pada pertemuan tersebut akan dinilai secara individual meskipun tampil bermain peran bersama anggota kelompok, sedangkan kelompok yang berperan sebagai penonton atau audiens diberi kesempatan untuk memberikan komentar atau tanggapan terhadap penampilan kelompok yang telah tampil. Pada pertemuan ketiga dalam siklus II ini siswa tampak lebih antusias dan bersemangat untuk memperbaiki penampilan dan keterampian berbicara.

Hasil refleksi yang dilakukan oleh guru dan kolaborator berdasarkan pengamatan pada proses pembelajaran 1 sampai 3 siklus II, melalui pengamatan dan penilaian proses menghasilkan kesimpulan bahwa metode bermain peran sebagai metode utama dalam pembelajaran berbicara pada siswa kelas V SD Negeri 58 Kota Bima dapat meningkatkan keterampilan berbicara siswa, memberi peluang agar siswa tidak malu dan takut untuk berbicara di depan kelas. Peningkatan ini berdasarkan hasil penilaian yang dilakukan secara individual selama proses bermain peran yang dilakukan oleh siswa bersama anggota kelompoknya masing-masing. Siswa tampak begitu antusias dan semangat untuk bermain peran. Secara kasat mata, siswa tampak seperti menemukan rasa percaya diri untuk berbicara di depan umum. Pada siklus II, kompetensi siswa mengalami peningkatan, hal ini dapat dilihat dari ke- 
mampuan siswa untuk membuat skenario percakapan, kemampuan siswa untuk meringkas percakapan dan keterampilan berbicara siswa pada saat bermain peran dan menanggapi penampilan kelompok lain. Keterampilan berbicara dari kelima aspek; tatabahasa, kosakata, pemahaman, kefasihan, dan pengucapan siswa pada siklus II sangatlah baik berdasarkan data yang disajikan pada tabel di bawah ini.

Tabel 3. Data Keterampilan Berbicara Siswa pada Siklus II

\begin{tabular}{clcl}
\hline Kriteria & Kategori & Frekuensi & Persentase \\
\hline 5 & sangat baik & 13 & $56,52 \%$ \\
4 & baik & 10 & $43,48 \%$ \\
3 & cukup & 0 & $0 \%$ \\
2 & kurang & 0 & $0 \%$ \\
1 & sangat kurang & 0 & $0 \%$ \\
Jumlah & & 23 & $100 \%$ \\
\hline
\end{tabular}

Berdasarkan Tabel 3 di atas diketahui bahwa $56,52 \%$ siswa atau 13 orang memiliki keterampilan berbicara sangat baik, sedangkan $43,48 \%$ siswa atau 10 orang memiliki keterampilan berbicara baik.

Dari siklus I ke siklus II keterampilan berbicara siswa mengalami peningkatan seperti yang diharapkan sebagai indikator keberhasilan, baik dari aspek tatabahasa, kosakata, pemahaman, kefasihan maupun pengucapan. Peningkatan tersebut terjadi karena adanya beberapa perubahan pengelolaan dan modivikasi langkah yang dilakukan pada siklus II. Perubahan tersebut berupa perubahan modeling berupa pemutaran vidio singkat tentang orang yang melakukan dialog sehingga siswa terinspirasi, perubahan materi, dan perubahan anggota kelompok yang dianggap tidak bisa bekerja sama pada siklus I.
Tabel 4. Rekap Analisis Keterampilan Berbicara Siswa

\begin{tabular}{lccc}
\hline $\begin{array}{c}\text { Aspek yang } \\
\text { dinilai }\end{array}$ & $\begin{array}{c}\text { Siklus } \\
\text { I }\end{array}$ & $\begin{array}{c}\text { Siklus } \\
\text { II }\end{array}$ & Peningkatan \\
\hline Tatabahasa & 3,65 & 3,74 & 0,09 \\
Kosakata & 3,65 & 3,70 & 0,05 \\
Pemahaman & 4,00 & 4,17 & 0,17 \\
Kefasihan & 4,00 & 4,13 & 0,13 \\
Pengucapan & 4,35 & 4,52 & 0,17 \\
Total rerata & 3,93 & 4,05 & 0,61 \\
\hline
\end{tabular}

Keterampilan berbicara rata-rata kelas pada lima aspek keterampilan berbicara siswa yang digambarkan di bawah ini, menunjukkan bahwa keterampilan berbicara siswa telah meningkat pada siklus II, ini berarti bahwa tindakan yang dilakukan dalam penelitian ini telah mencapai indicator keberhasilan yang diharapkan, yaitu skor rata-rata keterampilan berbicara siswa mencapai di atas 75,00 atau berkategori baik, dan ketuntasan belajar klassikal mencapai $75 \%$.

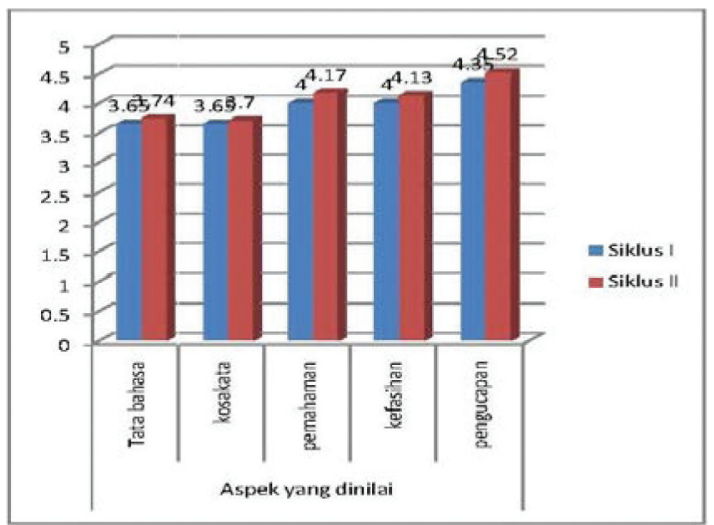

Gambar 1. Peningkatan Rata-rata Kelas Aspek Keterampilan Berbicara Siswa Siklus I dan II

Hal lain yang ditemukan pasca pemberian tindakan pada siklus II adalah bahwa melalui kegiatan kelompok siswa menjadi lebih aktif untuk berpikir, lebih bertanggung jawab untuk menyelesaikan tugas yang diberikan, mau bekerjasama dengan anggota kelompok dan menjalin komunikasi yang baik antara yang satu 
dengan yang lainnya. Ini berarti bahwa siswa memiliki minat dan semangat untuk belajar dan menyelesaikan tugas yang diberikan oleh guru.

Tabel 5. Data Presentase Siswa yang Sesuai dengan Indikator dalam Aktifitas Kerja Kelompok

\begin{tabular}{llccc}
\hline No & \multicolumn{1}{c}{$\begin{array}{c}\text { Aspek yang } \\
\text { diamati }\end{array}$} & \multicolumn{3}{c}{$\begin{array}{c}\text { Pertemuan } \\
\text { ke (\%) }\end{array}$} \\
\hline & & I & II & III \\
1 & Terlibat aktif & 74,29 & 88,57 & 91,43 \\
2 & Bekerjasama & 91,43 & 91,43 & 94,29 \\
3 & Menghargai & 88,57 & 91,43 & 97,14 \\
& kontribusi & & & \\
4 & Bertanggungjawab & 85,71 & 91,43 & 97,14 \\
5 & Menjalin komunikasi & 97,14 & 100 & 100 \\
\hline
\end{tabular}

Kegiatan individual siswapun mengalami peningkatan pada siklus II, selain bisa bekerjasama dan bertanggungjawab untuk menyelesaikan tugas secara kelompok, siswa juga menjadi lebih berinisiatif mencari inspirasi untuk mengungkapkan ide dan gagasan dan lebih berani tampil di depan kelas dengan penuh percaya diri.

Aspek aktifitas siswa dari siklus I ke siklus II juga mengalami peningkatan, pada siklus I; kerjasama 76, tanggungjawab 87, inisiatif 83, dan keberanian 78, berarti rata-rata kelas 81 , sedangkan pada siklus II meningkat menjadi; kerjasama 87, tanggungjawab 93, inisiatif 93, dan keberanian 95, berarti rata rata kelas 92, seperti yang ditunjukkan pada gambar 2 .

Keberhasilan penelitian ini tidak hanya terjadi pada peningkatan keterampilan berbicara siswa dan peningkatan aktifitas siswa secara kelompok maupun secara individual, tetapi keberhasilan juga terjadi pada pihak guru dalam pelaksanaan pembelajaran. Aktivitas guru dalam pelaksanaan pembelajaran dengan metode bermain peran diperoleh rerata skor 69,09 pada siklus I, dan pada siklus II menjadi 88,18 , berarti telah terjadi peningkatan senilai 19,09 point.

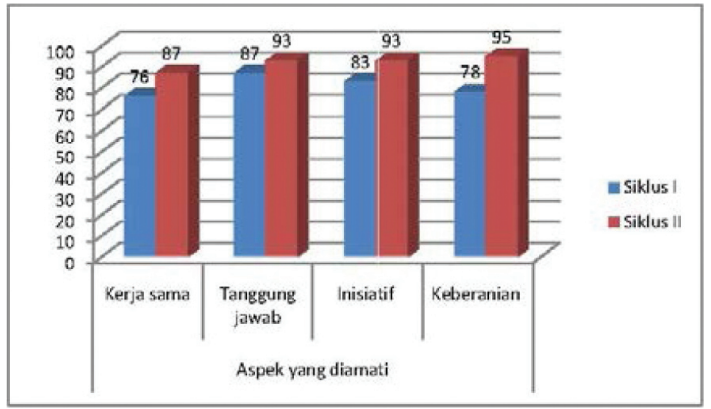

Gambar 2. Peningkatan Aspek Aktifitas Siswa dalam Proses Pembelajaran Siklus I dan II

Tabel 6. Peningkatan Aktivitas Guru pada Kegiatan Pembelajaran Siklus I dan I

\begin{tabular}{lccc}
\hline $\begin{array}{c}\text { Aspek yang } \\
\text { Diamati }\end{array}$ & Siklus 1 & Siklus 2 & Peningkatan \\
\hline Kegiatan Awal & 70,00 & 90,00 & \\
Kegiatan Inti & 68.09 & 87,78 & \\
Penutup & 70,00 & 90,00 & \\
Rerata Total & $\mathbf{6 9 , 0 9}$ & $\mathbf{8 8 , 1 8}$ & $\mathbf{1 9 , 0 9}$ \\
\hline
\end{tabular}

Data peningkatan aktifitas guru dalam pembelajaran dapat dilihat dalam gambar 3 .

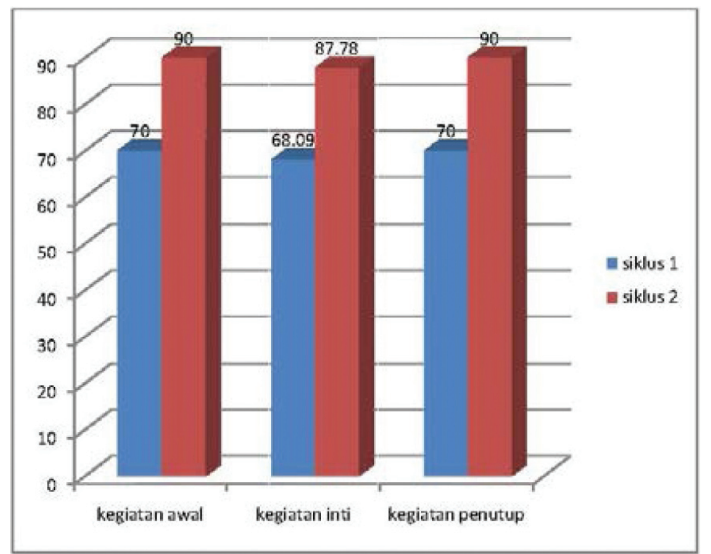

Gambar 3. Peningkatan Aktivitas Guru Pembelajaran Siklus I dan II

\section{PENUTUP \\ Simpulan}

Berdasarkan hasil penelitian, dan analisa data menunjukkan bahwa: 1) Penerapan metode bermain peran dapat meningkatkan keterampilan berbicara siswa. Hal tersebut dapat dilihat dari skor rata-rata 
siswa 78, 61 pada siklus 1 dengan klasifikasi baik, dan skor rata-rata siswa siklus 2 menjadi 81,04 dengan klasifikasi sangat baik, 2) Aktivitas siswa dalam proses pembelajaran dengan menggunakan metode bermain peran mengalami peningkatan dari rata-rata 81,00 pada siklus 1 menjadi 92,00 pada siklus 2 dengan kategori sangat baik. Pelaksanaan tindakan menggunakan metode bermain peran telah mencapai indikator keberhasilan dalam penelitian ini yakni skor perolehan rata-rata keterampilan berbicara siswa $\geq 75,00$ dan ketuntasan belajar klassikal mencapai $75 \%$. 3) Peningkatan keterampilan berbicara dan proses pembelajaran disebabkan karena adanya perubahan prosedur teknik, perubahan materi, dan perubahan anggota kelompok.

\section{Saran}

Penelitian ini difokuskan pada peningkatan keterampilan berbicara siswa melalui penggunaan metode bermain peran. Penilaian keterampilam berbicara dilakukan pada proses pembelajaran, jadi tidak menjamin siswa terampil berbicara dalam interaksi sosial di masyarakat. Diharapkan pada semua pihak agar membiasakan siswa untuk menggunakan bahasa Indonesia dalam keidupan sehari-hari.

\section{DAFTAR PUSTAKA}

Brown, H.D. (2001). Teaching by principels: an interactive approach to language pedagogy. New York: Pearson Education Company.
Kerr, et.al, (2003). The use of role playing to help students understand information systems case studies. Journal of Information Systems Education. Australia, 14 (2), 167.

Mulyatiningsih, E. (2011). Riset terapan bidang pendidikan dan teknik. Yogyakarta: UNY Press.

Nurgiyantoro, B. (2012). Penilaian pembelajaran bahasa. Yogyakarta: BPFEYogyakarta.

Pardjono, dkk. (2007). Panduan penelitian tindakan kelas. Yogyakarta: Lembaga Penelitian UNY.

Patricia, A., \& Amato, R. (2003). Making it happen from interactive to participatory language teaching, theory and practice. New York: Pearson Education, Inc.

Richard, J. C. \& Renandya, W. A. (2002). Methodology in language teaching. New York: Cambridge University Press.

Santrock, J. W. (2012). Perkembangan masa-hidup. (Terjemahan Benedictine Widyasinta). New York: McGraw-Hill Companies.

Suwandi, S. ( 2009). Model assesmen dalam pembelajaran. Surakarta: Mata Padi Presindo.

Tarigan H. G. (2008). Berbicara sebagai suatu keterampilan berbahasa. Bandung: Angkasa.

Widoyoko, E. P. (2013). Evaluasi program pembelajaran panduan praktis bagi pendidik dan calon pendidik. Yogyakarta: Pustaka Pelajar. 